\title{
On gallic acid
}

\section{Robiquet}

To cite this article: M. Robiquet (1837) On gallic acid, Philosophical Magazine Series 3, 11:67, 323-324, DOI: $10.1080 / 14786443708649283$

To link to this article: http://dx.doi.org/10.1080/14786443708649283

册 Published online: 01 Jun 2009.

Submit your article to this journal 정

Џll Article views: 2

Q View related articles $₫$ 
acid $(\ddot{S}+\ddot{s})$ but two atoms of sulphuric acid united to an atom of sulphurous acid $(2 \dddot{\mathrm{S}}+\ddot{\mathrm{S}})$, which by calculation gives in a hundred parts

Sulphurous acid........ 2858

Sulphuric acid $\ldots \ldots \ldots, 71 \cdot 42$

$100 \cdot 00$

As the sulphurous acid is that which exists in the least proportion in this combination, it may be considered as the basic constituent, and in this point of view the compound is a neutral sulphate(bi-sulphate?) in which the sulphuric acid contains thrice as much oxygen as the base.-Journal de Pharmacie, March 1837.

ON GaLliC ACID. BY M. ROBIQUET.

M. Robiquet remarks that before M. Pelouze had published his work on tannin and gallic acid, it was generally admitted that the acid was ready formed in the gall nut, and it was far from being supposed, as attempted to be shown by this chemist, that gillic acid was entirely derived from the tamin. M. Robiquet, after stating some difficulties in admitting this opinion, observes, that whether the acid pre-exists or not in the gall nut, it is certain that a large quantity separates independently of contact with the air or with oxygen, and without any action, if indeed there be one, which occasions the evolution of any gas.

M. Robiquet then details experiments which show that tannin roes not yield much above half its weight of gallic acid; and he observes that there is great disproportion between the time required to convert pure tannin into gallic acid and that required for the entire gall nut. In the latter case a month is sufficient in favourable weather to complete the action. He is therefore of opinion that the gall nut contains other principles, which facilitate the operation by acting as a kind of ferment, and M. Robiquet supposes that the gum, or rather mucilage, which may be separated by water from the residue after the action of ather upon the gall nut, performs this office.

Following out the opinion formerly stated by M. Chevreul, that tannin may be a compound of which gallic acid is one of the elements, M. Robiquet examined whether this idea was probable, and the results were the following: $M$. Pelouze had inferred from his analysis of tannin that it consisted of $\mathrm{C}^{18} \mathrm{H}^{18} \mathrm{O}^{12}$. M. Liebig has since remarked that the analy sis agrees better with $\mathrm{C}^{\mathrm{is}} \mathrm{H}^{16} \mathrm{O}$, and preferred the latter as more easily explaining the conversion of tanthin into gallic acid. M. Pelouze nevertheless retained the first formula, and $\mathrm{M}$. Robiguet adopts it as agreeing better with his new view of the subject. Thus, this formula $\mathrm{C}^{18} \mathrm{H}^{1 \times} \mathrm{O}^{12}=\left(\mathrm{C}^{\prime} \mathrm{H}^{\prime \prime} \mathrm{O}^{\prime}+\mathrm{H}^{2} \mathrm{O}\right)$ $+\mathrm{H}^{2} \mathrm{C}^{4}$ represents 2 atoms of crystallized gallic acid, plus 1 atom of a carburetted hydrogen of the same composition as benzin. The formula adopted by M. Liebig will equally apply to other changes. Thus, the 3 atoms of tannin are equivalent to 6 atoms of gallic acid, plus 2 atoms of dry pyrogallic acid, $3\left(\mathrm{C}^{16} \mathrm{H}^{16} \mathrm{O}^{12}\right)=\mathrm{C}^{5+} \mathrm{H}^{18} \mathrm{O}^{16}=$ $6\left(\mathrm{C}^{-} \mathrm{H}^{6} \mathrm{O}^{5}\right)+2\left(\mathrm{C}^{6} \mathrm{H}^{i} \mathrm{O}^{i}\right)$; or still better, by admitting that tan- 
nin may absorb an atom of water, there would result gallic and acetic

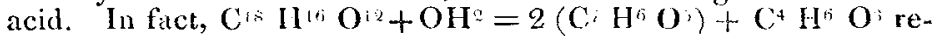
presents 2 atoms of gallic acid and 1 atom of acetic acid.-Journal de Chimie Medicale, Mai 1837.

\section{SPONTANEOUS COMBUSTION OF LINSEED OLL AFTER ITS BE- COMING DRY.}

The heating of linseed oil when soaking into soft vegetable fibrous or porous matters, has been several times brought into public notice; but we have not observed this effect when the oil has become dry and hard.

A manufacturer at Plymouth had occasion, two or three years since, to grind some red lead in oil, and a cask of it was set aside till it had become hard, and consequently useless, which soon happens to that mixture, red lead being a rapid " dryer." Some months since, being annoyed at this cask lying about the warehouse, he ordered it to be knocked to pieces and the contents powdered, to see if anything could be made of it. This being done in the evening, and the powder put into a box, he was surprised in the morning by a smell of fire, and atter searching the warehouse over, perceived smoke issuing from this box; water was thrown in, and when all was cold the contents were turned out. The bottom of the box was found charred, the matter next it brown and partly reduced, and so to about the centre of the mass, from whence it shaded off through chocolate colour to the surface, which retained its redness, but was clotted hard together like all the rest.

The same manufacturer has occasion for large quantities of oiled paper, which when quite dry and no longer adhesive to the touch, he has sometimes put together in piles, but has been obliged to separate them again on account of the heat generated, which has been such as to threaten ignition.

August 5, 1837 .

PROCESS FOR INK DEVOID OF FREE ACID. BY R. HARE, M.D. PROFESSOR OF CIIEMISTRY IN THIE UNIVEISITY OF PENNSYLVANIA.*

Writing ink is usually constituted of the tanno-gallate of iron and a portion of sulphuric acid, which had existed in the copperas or sulphate of iron employed as one of its ingredients, the tanno-gallate being suspended and the acid dissolved in the water. This free acid is injurious to iron pens. Dr. Hare has observed that when an infusion of galls is kept over finery cinder till saturated, it forms a bcautiful ink, in which of course there is no free acid.

This ink is rather more prone to precipitate than that made with sulphate of iron, and this propensity is not counteracted by the addition of gum arabic. But, on the other hand, it has the advantage of being easily suspended again by agitation, not forming any concrete matter insusceptible, like common ink grounds, of that distribution in water which is necessary to good ink. The tanno-gallate

* The atove and three following notices have been communicated by the anthor, 